\title{
Fluorescent Tag Type
}

National Cancer Institute

\section{Source}

National Cancer Institute. Fluorescent Tag Type. NCI Thesaurus. Code C139282.

The type of fluorescent label or dye that is used in a fluorescence-based assay. 